\title{
A $\quad 1.9$ Ga glacial sedimentary-facies association at low palaeolatitude in the Bergslagen Group, Grythyttan Field, Central Sweden
}

\author{
Gerrit Kuipers ${ }^{1}$, Frank F. Beunk ${ }^{2}$, Keewook Yi ${ }^{3}$ \& Frederik M. van der Wateren ${ }^{4}$ \\ ${ }^{1}$ Stroom 171, 9406 EL Assen, the Netherlands. \\ ${ }^{2}$ Vrije Universiteit, Faculty of Science (Dept. Earth Sciences), De Boelelaan 1085, 1081 HV Amsterdam, \\ the Netherlands. \\ ${ }^{3}$ Division of Earth and Environmental Sciences, Korean Basic Science Institute (KBSI), Ochang 363-833, Korea. \\ ${ }^{4}$ Cas Oorthuyskade 23, 1087 DP Amsterdam, the Netherlands. \\ E-mail corresponding author (Gerrit Kuipers): kuipersgerrit@gmail.com
}

\section{Keywords: \\ - Periglacial \\ - Diamictite \\ - Olistolith \\ - Palaeoproterozoic \\ - Snowball Earth}

\section{Received:}

28. April 2020

Accepted:

4. December 2020

Published online:

9. February 2021
Glacial sedimentary facies are recognised in the Palaeoproterozoic (Orosirian) Bergslagen Group in central Sweden, described previously as post-orogenic conglomerates in the Grythyttan Field. The evidence is provided by the presence of macro boulders in a megaclastic to conglomerate rock formation or diamictite around lake Brunnsjön, south of Grythyttan. Pebble to cobble size conglomerates discordantly overlie a megaclastic rock formation, with facetted clasts resembling flatirons. The sedimentary facies assemblage resembles an ice-front resedimented sequence, previously interpreted as an alluvial fan by the writers. A glacial interpretation is supported by evidence of permafrost and related periglacial structures in coeval, $1895 \pm 5 \mathrm{Ma}$ (U-Pb zircon age), metavolcaniclastic rocks in the Bergslagen Group. The association of glacial sedimentary facies, permafrost and banded ironstones in the low-latitudinal Bergslagen Group suggests its similarity to better known 'Snowball Earth' deposits from Palaeoproterozoic and particularly Neoproterozoic times.

\section{Introduction}

Severe, occasionally global ('Snowball Earth') glaciations occurred at several times during the Proterozoic Eon, but were conspicuously absent during a long Palaeo-Mesoproterozoic non-glacial interval (c. $2.3 \mathrm{Ga}$ to 750 Ma; Eyles, 2008), known as the 'Proterozoic glacial gap' (Fig. 1). The identification of an ice-wedge cast and related periglacial structures (Kuipers et al., 2013; Vandenberghe et al., 2020) in the dominantly marine, c. 1.9 Ga old, Orosirian, volcanosedimentary Bergslagen Group (Beunk \& Kuipers, 2012) in the Svecofennian orogen of the Fennoscandian Shield in Sweden hints at an as yet little known glaciation during an apparent glacial gap. Previous paleomagnetic studies have assigned a tropical palaeolatitude to the Fennoscandian Shield as a whole (Pesonen et al., 2012; Mertanen \& Pesonen, 2012), along a planetary scale, active and accretionary continental margin which assembled the supercontinent Columbia.

Kuipers, G., Beunk, F.F., Yi, K. \& van der Wateren, F.M. 2021: A 1.9 Ga glacial sedimentary-facies association at low palaeolatitude in the Bergslagen Group, Grythyttan Field, Central Sweden. Norwegian Journal of Geology 101, 202101. https://dx.doi.org/10.17850/njg101-1-1.

(c) Copyright the authors.

This work is licensed under a Creative Commons Attribution 4.0 International License. 


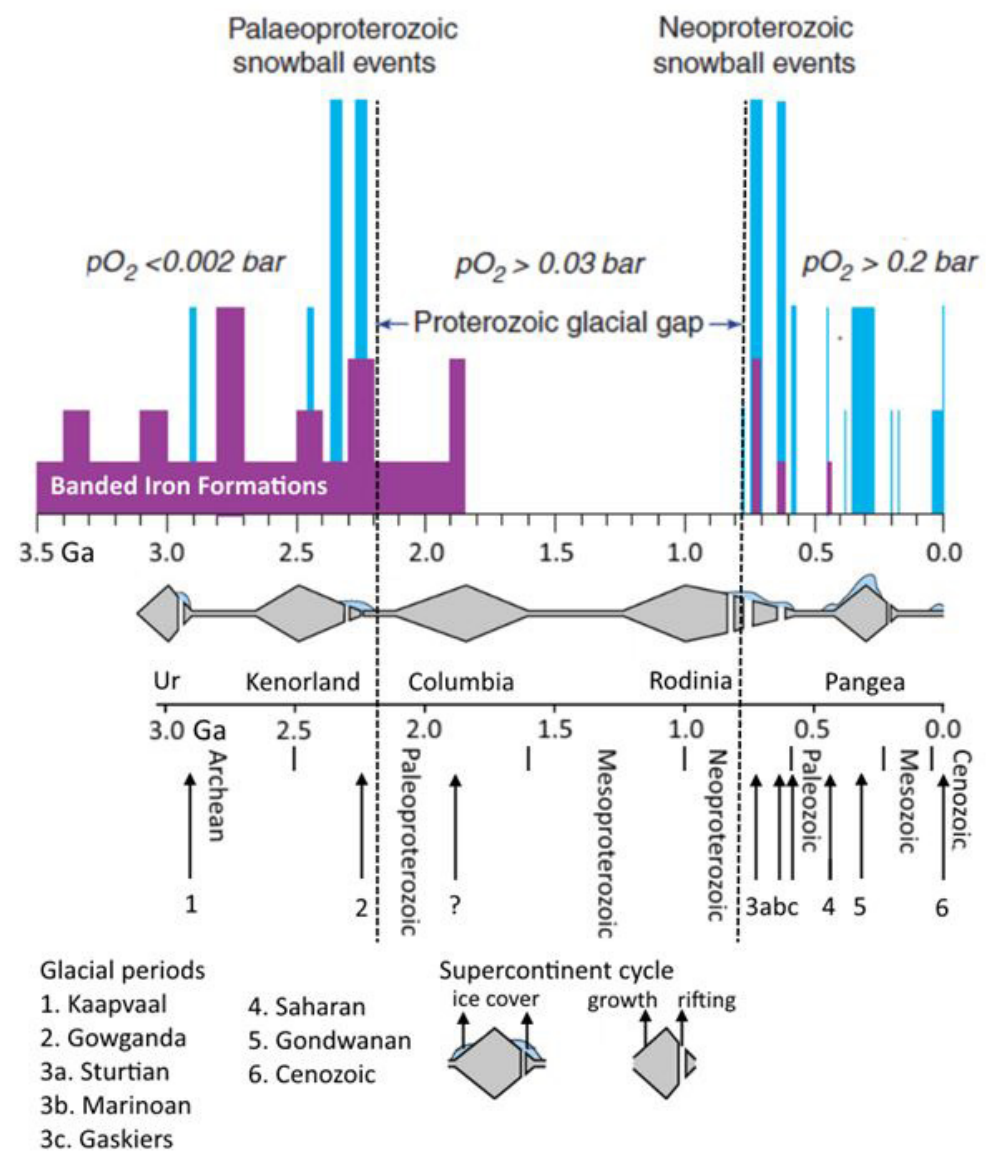

Figure 1. Diagrammatic representation of the problem: Temporal distribution of glacial periods (blue bars and black arrows), banded iron formations (purple bars), and supercontinents (grey band) since 3.0 Ga BP. The occurrence of BIFs correlates fairly well with glacial periods, but BIFs of the period 1.9-1.8 Ga, during construction of the supercontinent Columbia, are a notable exception (adapted from Hoffman \& Schrag, 2002, and Eyles, 2008).

The suggestion of a glacial palaeoclimate at low latitude and elevation stimulated us to scrutinise the Bergslagen Group (BG) for additional evidence of a (peri-)glacial sedimentary environment. Herein, we will describe an ice-front sedimentary facies association in the southern Grythyttan Field (GF), previously dated at c. $1895 \mathrm{Ma}$ (Kuipers et al., 2018).

\section{Geological setting}

The Bergslagen Group forms a bimodal, but dominantly felsic, metavolcanic to siliciclastic suite in the Svecofennian orogen of south-central Sweden (Fig. 2). Maximum total stratigraphic thickness was estimated at about $10 \mathrm{~km}$ (Allen et al., 1996; Stephens et al., 2009). The Group has been dated from different, widespread locations to approximately 1.91-1.89 Ga (Stephens et al., 2009). Shallow submarine deposition prevailed, as witnessed by a variety of sedimentological, mineralogical and geochemical details, but occasionally subaerial conditions prevailed (for references see Kuipers et al., 2018). Throughout Bergslagen the BG is accompanied by a synvolcanic intrusive suite of 'older' granites, diorites and gabbros (GDG suite; Stephens et al., 2009; Fig. 2). Bergslagen is part of the accretional continental margin of the supercontinent Columbia-under-construction (Rogers \& Santosh, 2002; Zhao et al., 2004; Nance et al., 2014; Meert \& Santosh, 2017), and, on geochemical and ore geological grounds, has been interpreted as a continental intra-arc or back-arc basin (e.g., Beunk \& Valbracht, 1991; Allen et al., 1996). Beunk \& Kuipers (2012) interpreted Bergslagen as a micro- 


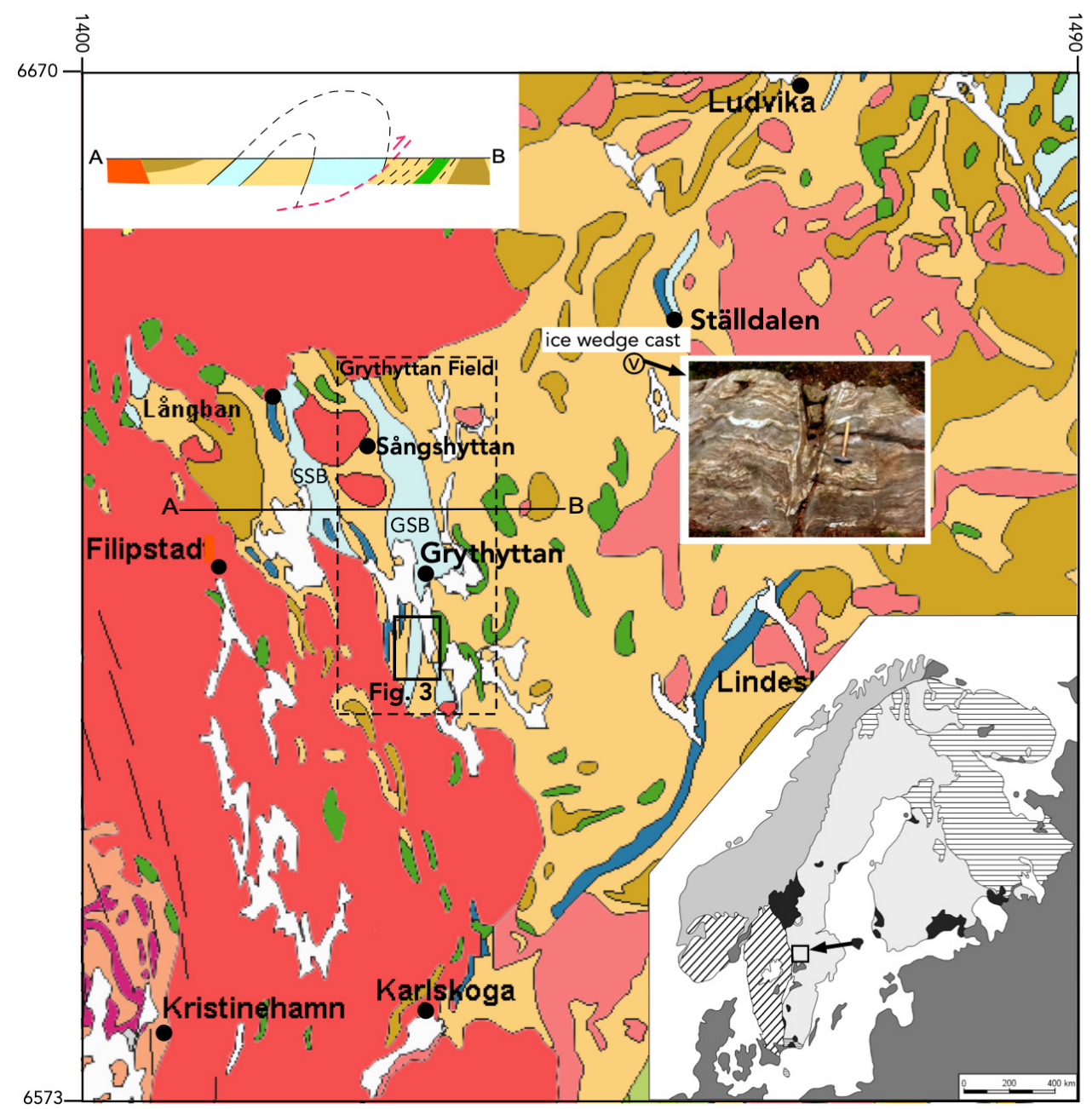

Figure 2. Geological map of the Filipstad-Ludvika-Lindesberg region, containing the Grythyttan Field in western Bergslagen, modified from the geological bedrock map of Sweden, 1:1 250 000. (c) Geological Survey of Sweden (SGU), with location of the suspected glacigenic sediments, Fig. 3. Coordinates: Swedish RT90 grid (km units). Legend: ochre - 'older', synvolcanic Svecofennian (GDG) granites; pink - 'younger' Svecofennian (GSDG) granites; red - postSvecofennian granites (TIB). Bergslagen Group: yellow - felsic metavolcanic rocks; light blue - metasedimentary rocks; green - mafic metavolcanic rocks; dark blue - dolomites. White - lakes. SSB - Saxån Slate Belt; GSB - Grythyttan Slate Belt. The inset in the lower right corner shows the location of main map in the Fennoscandian Shield (arrowed): Horizontal ruling - Archaean cratons; light grey - Palaeoproterozoic Svecofennian orogen; black - Mesoproterozoic intrusions; diagonal ruling - Neoproterozoic Sveconorwegian (Grenvillian) orogen; medium grey - Caledonian orogen; darkgrey-Phanerozoic cover. Inset top left showing cross-section $A B$, with an east-vergent anticline between 'older (GDG) granites'; east-vergent thrusting reactivated a synsedimentary extensional (caldera rim?) fault (Kuipers et al., 2018). Note location and image of ice-wedge cast (Kuipers et al., 2013).

continental accreted block within the Svecofennian orogen. It experienced two phases of folding, earlier tight upright folds, sheared and refolded along vertical axes during terrane accretion and oroclinal bending (Beunk and Kuipers, 2012). Most of the terrane experienced syntectonic amphibolite- to locally (in the east) granulite-facies metamorphism, overprinted by a pronounced annealing recrystallisation. The BG has been mined since the Middle Ages for synsedimentary mineral deposits, particularly for volcanic-hosted massive sulphides and banded ironstones, and for skarn ores. The geological map (Fig. 2) includes a low greenschist-facies metamorphic subdomain of the BG also known as the Grythyttan Field (GF), described in theses by Sundius (1923) and Kuipers (1987); it is intruded on its western side by granites of the post-Svecofennian, $<1.8 \mathrm{Ga}$ Transscandinavian Igneous Belt (TIB). The stratigraphy, structure and age of the GF have recently been re-assessed by Kuipers et al. (2018). The subparallel Saxån Slate Belt (SSB) and the Grythyttan Slate Belt (GSB) mark the western and 
eastern limbs of a N-S-trending, east-vergent, map-scale anticline, resulting from upright folding (D2) of the previously extended back-arc or intra-arc basin (D1). The east-younging eastern fold limb includes the GSB and dips subvertically, slightly overturned to the west; see inset, top left corner of Fig. 2.

\section{Observations in the southern part of the GSB (south of Grythyttan township)}

We will focus on the southern extension of the Grythyttan Slate Belt (Figs. 2 \& 3). Stratigraphic details are cited from the more elaborate description of the lithostratigraphy by Kuipers et al. (2018). The area around lake Brunnsjön (Fig. 3) exposes the volcanosedimentary Sångshyttan Formation of the BG in the west, overlain towards the east by the Grythyttan Slate Formation. The lowest unit of the latter is the Saxhyttan Member. It is represented by a slaty to pebbly diamictite in this part of the GSB, discordantly overlain by the, on average, $1 \mathrm{~km}$-thick Torrvarpen conglomerate consisting of numerous heterolithic debris flows, making up a significant percentage of the alluvial fan. The debris flows are lens shaped in transverse cross-section and conformably overlain by the Lonnhöjden submember; this is the proximal volcaniclastic part of the Hällefors member (Fig. 4). The Jordan member is virtually missing, except for a small outcrop of Grythyttan black slate on the north shore of lake Sirsjön. The following subsections present observations relevant for the facies interpretation of the Saxhyttan member.
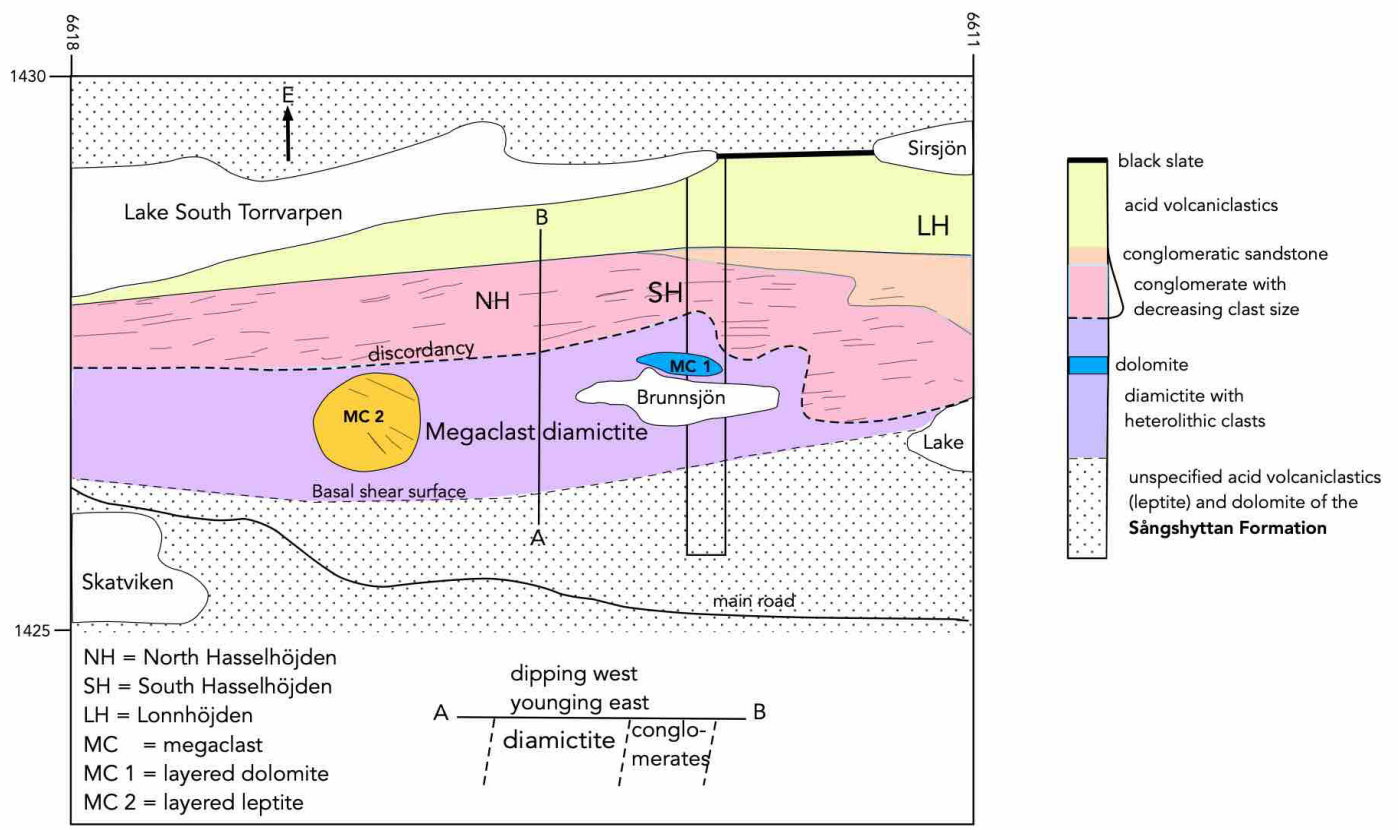

Figure 3. Sedimentary facies map, $5 \times 7 \mathrm{~km}$, of the southern Grythyttan Slate Belt with megaclasts in the Brunnsjön diamictite (a new subdision of the Saxhyttan member of the Grythyttan formation), discordantly overlain by the Torrvarpen conglomerate subdivision. MC 1 = lone dolomite megaclast; MC 2 = lone Mg-rich leptite megaclast, both are internally thick bedded. RT90 coordinates in km units.

Grythyttan Slate Formation

Jordan member

Grythyttan black slates

\section{Hällefors member}

left $=$ grey slate

right $=$ acid volcaniclastics

Saxhyttan member

left = diamictite

right $=$ conglomerate
Figure 4. Simplified list of lithostratigraphic subdivisions in the Grythyttan Slate Formation (Kuipers et al., 2018). The lower part of the Saxhyttan member (Brunnsjön submember) is recognised as a diamictite. 


\section{Torrvarpen conglomerates}

Most clasts derive from the underlying metavolcanic rocks. Along the best exposed E-W section directly south of Lake Brunssjön, clasts are generally well rounded, albeit of low sphericity (Lisle et al., 1983). Angular, facetted clasts from underlying felsic volcanites (leptites) are not uncommon (Fig. 5A, B). Angular clasts of single-grained quartz and multigrain quartzite clasts are present in thin-section, but seldom in outcrops. Limestone clasts are observed only in thin-sections (Fig. 5C). Subrounded slate fragments are locally abundant (Fig. 5D). In contrast to the generally well-rounded conglomerates in S. Hasselhöjden, an angular leptite breccia occurs in N. Hasselhöjden approximately along the profile $A B$ of Fig. 2 (Fig. 5E). We will suggest its significance in the Discussion paragraph.

\section{Brunnsjön diamictite, a new submember of the Sax- hyttan member of the Grythyttan Slate Formation}

This section concentrates on observations in the basal part of the pebbly slates forming the Saxhyttan Member of the Grythyttan Slate Formation, here named the Brunnsjön diamictite (Tucker, 2003); it provides the main argument of our contribution suggesting that we are dealing with a glacial sedimentary facies association previously described as an alluvial fan by Kuipers \& Beunk (2014). Sporadic lonestones in the upper part of the diamictite may represent dropstones (Fig. 5F). The presence of an isolated $1100 \times 300$ m megaclast of dolomite east of lake Brunnsjön (Fig. 3) has been known since Sundius (1923), who incorporated it in the base of the Torrvarpen (Älvestorp conglomerate, he named them) conglomerates farther east. Analysis of aerial photographs resulted in the identification of an even larger megaclast of bedded magnesium-rich leptites farther north (Figs. 3 \& 5C). The dolomitic and leptitic megaclasts (Terry \& Goff, 2014) are thick bedded and harder than the surrounding pebbly diamictite around lake Brunnsjön, creating elevations in the landscape as a consequence (Fig. 5G). Sedimentary macrostructure reveals a westward younging of the dolomite megaclast in Fig. $5 \mathrm{H}$, which is opposite to its east-younging host rock. Internal bedding in the leptite megaclast is $\mathrm{C.} 30^{\circ}$ discordant to the regional $\mathrm{N}-\mathrm{S}$ strike of the bedrock (Fig. 3 ).

\section{Age constraints}

The depositional age of the glacigenic debris flows (Torrvarpen conglomerates) in the GSB was bracketed by $\mathrm{U}-\mathrm{Pb}$ zircon age determinations from metavolcanic sedimentary rocks below and above the conglomerates (1894.5 $\pm 2.8 \mathrm{Ma}$; Kuipers et al., 2018), and they also bracket the megaclastic diamictite (Fig. 2). Within error, these glacigenic deposits are coeval with the metadacites in which the ice wedge pseudomorph formed near Ställdalen (Table 1; Figs. 2, 6 \& 7; Kuipers et al., 2013; Vandenberghe et al., 2020). Because of the important support that the ice-wedge pseudomorph provides for the palaeoclimatic implications of the Brunnsjön diamictite, we report here the details of $\mathrm{U}-\mathrm{Pb}$ zircon dating of the metadacitic volcaniclastics of the BG hosting the pseudomorph. We collected one rock sample from the level at the top of the ice-wedge cast (sample Bk1336), which predates formation of the cast, and a second one (Bk1337) c. $1.5 \mathrm{~m}$ stratigraphically higher. The rocks are oligoclase-bearing biotite quartzites exhibiting $\mathrm{mm}$ - to $\mathrm{cm}$-scale microscopic modal banding in colour index, and a relict foliation expressed by greenish-brown biotites. They have a blastoporphyritic texture, with sparse, $c$. $1 \mathrm{~mm}$ size, oligoclase and quartz crystals representing former microphenocrysts in a matrix of 50-200 micrometre diameter grain size. Blue-green amphibole is present at $<1$ vol.\%. Other accessory minerals are magnetite $>$ titanite and its intergrowths with opaque phase(s) > apatite and zircon. This part of the BG experienced Svecofennian amphibolite-facies metamorphism. Incipient retrogression is expressed by minor chlorite after biotite and amphibole. 

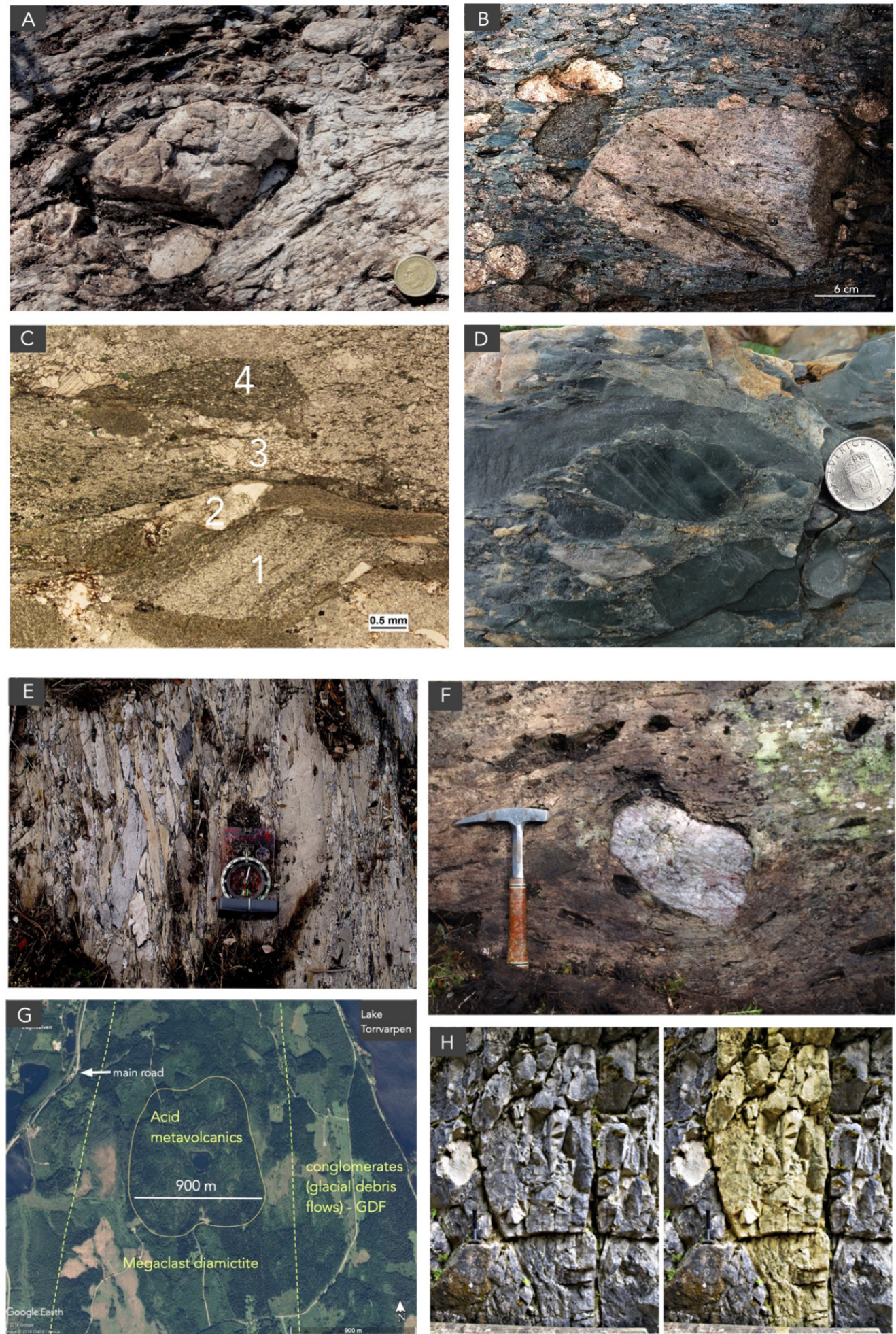

Figure 5. Field and microscope pictures, Grythyttan Field. (A, B) Suspected flatiron-type facetted clasts in Torrvarpen conglomerate, S. Hasselhöjden RT90 [6612495/1428010, 6612486/1427703]. Top surface in (B) shows faint striation marks. It could be a glacial erratic as it shows flat and curved surfaces. Diameter of the coin is $2 \mathrm{~cm}$. (C) Photomicrograph (plane-polarised light) of part of sample Bk1103 (661325/142765): 1. angular clast of bedded fine-grained sediment; 2. angular quartz grain; 3. flattened limestone pebble; 4. angular slate pebble. (D) Top surface of pebbly slates in the upper part of the Brunnsjön diamictite. Diameter of the coin is $2.5 \mathrm{~cm}$. (E) Breccia with angular metavolcanic clasts in Torrvarpen conglomerates (Udden-Wentworth scale), possible frost shatter. N. Hasselhöjden [6615069/1428070]. (F) Lonestone (possibly dropstone) in massive diamictite with angular shale clasts, in the upper part of the Brunnsjön diamictite. The lamination around the quartzite boulder is asymmetric. N. Hasselhöjden [661350/142764]. East is upwards. Hammer is $35 \mathrm{~cm}$ in length. (G) Suspected megaclast in doughnut-shaped hill, with small lake in centre [661578/142693]. West of lake S. Torrvarpen (from Google Earth). (H) Looking south at west-facing channel, coloured in right half, in steeply dipping dolomitic limestone (vertical exposure $2 \times 3 \mathrm{~m}$ ), in main entrance of quarry in limestone megaclast east of Lake Brunnsjön [661338/142739]. 
Table 1. $U$ and Th concentrations and U-Th-Pb isotopic results of all analysed spots. Spot identifier in first column. Pbc and Pb* indicate the common and radiogenic portions, respectively. ${ }^{206} \mathrm{~Pb} /{ }^{38} \mathrm{U}$ age and ${ }^{207} \mathrm{~Pb} /{ }^{206} \mathrm{~Pb}$ age have common $\mathrm{Pb}$ corrected using measured ${ }^{204} \mathrm{~Pb}$. Disc. $=$ percentage of positive or negative age discordance.

\section{Bk1336 RT90 lat/long: 6642559/1449751}

Spot\# $U \quad T h \quad T h / U \quad{ }^{206} \mathrm{~Pb}_{\mathrm{c}}(\%) \quad{ }^{238} \mathrm{U} /{ }^{206} \mathrm{~Pb}^{*} \quad \pm \quad \pm \% \quad{ }^{207} \mathrm{~Pb} * /{ }^{206} \mathrm{~Pb}^{*} \quad \pm \quad \pm \quad{ }^{206} \mathrm{~Pb} /{ }^{238} \mathrm{U} \quad{ }^{1 \sigma} \quad{ }^{207} \mathrm{~Pb} /{ }^{206} \mathrm{~Pb} \quad{ }^{1 \sigma} \quad \mathrm{Disc}$. (ppm) (ppm)

age (Ma) age (Ma)

\begin{tabular}{|c|c|c|c|c|c|c|c|c|c|c|c|c|c|}
\hline 1.1 & 130 & 57 & 0.44 & 0.09 & 2.946 & 1.84 & 0.11610 & 0.62 & 1884 & \pm 30 & 1897 & \pm 11 & +1 \\
\hline 2.1 & 322 & 173 & 0.54 & -- & 2.981 & 1.15 & 0.11618 & 0.37 & 1865 & \pm 19 & 1898 & \pm 7 & +2 \\
\hline 3.1 & 625 & 474 & 0.76 & 0.03 & 3.057 & 2.02 & 0.11646 & 0.27 & 1825 & \pm 32 & 1903 & \pm 5 & +5 \\
\hline 4.1 & 117 & 32 & 0.28 & 0.14 & 2.901 & 0.80 & 0.11615 & 0.66 & 1909 & \pm 13 & 1898 & \pm 12 & -1 \\
\hline 5.1 & 388 & 204 & 0.52 & 0.01 & 2.329 & 1.04 & 0.15023 & 0.27 & 2303 & \pm 20 & 2349 & \pm 5 & +2 \\
\hline 6.1 & 231 & 90 & 0.39 & 0.13 & 2.939 & 1.14 & 0.11572 & 0.50 & 1888 & \pm 19 & 1891 & \pm 9 & +0 \\
\hline 7.1 & 204 & 96 & 0.47 & 0.04 & 2.827 & 0.95 & 0.11539 & 0.48 & 1952 & \pm 16 & 1886 & \pm 9 & -4 \\
\hline 8.1 & 1102 & 535 & 0.49 & 0.04 & 2.962 & 0.86 & 0.11597 & 0.21 & 1875 & \pm 14 & 1895 & \pm 4 & +1 \\
\hline 9.1 & 203 & 83 & 0.41 & 0.03 & 2.920 & 1.44 & 0.11590 & 0.46 & 1899 & \pm 24 & 1894 & \pm 8 & -0 \\
\hline 10.1 & 146 & 68 & 0.46 & 0.05 & 2.950 & 1.09 & 0.11630 & 0.55 & 1882 & \pm 18 & 1900 & \pm 10 & +1 \\
\hline 13.1 & 398 & 106 & 0.27 & 0.11 & 2.952 & 0.62 & 0.12106 & 0.35 & 1881 & \pm 10 & 1972 & \pm 6 & +5 \\
\hline 14.1 & 756 & 315 & 0.42 & 0.04 & 3.468 & 1.42 & 0.11144 & 0.70 & 1633 & \pm 21 & 1823 & \pm 13 & +12 \\
\hline 15.1 & 122 & 51 & 0.42 & 0.01 & 2.893 & 1.79 & 0.11536 & 0.59 & 1914 & \pm 13 & 1885 & \pm 11 & -2 \\
\hline
\end{tabular}

Bk1337 RT90 lat/long: 6642559/1449751

Spot\# $U \quad T h \quad T h / U \quad{ }^{206} \mathrm{~Pb}_{\mathrm{c}}(\%) \quad{ }^{238} \mathrm{U} /{ }^{206} \mathrm{~Pb}^{*} \quad \pm \% \quad{ }^{207} \mathrm{~Pb} * /{ }^{206} \mathrm{~Pb}^{*} \quad \pm \% \quad{ }^{206} \mathrm{~Pb} /{ }^{238} \mathrm{U} \quad{ }^{1 \sigma} \quad{ }^{207} \mathrm{~Pb} /{ }^{206} \mathrm{~Pb} \quad{ }^{1 \sigma} \quad \mathrm{Disc}$ (ppm) (ppm) age (Ma) age (Ma)

\begin{tabular}{|c|c|c|c|c|c|c|c|c|c|c|c|c|c|}
\hline 1.1 & 503 & 120 & 0.24 & 0.04 & 2.842 & 1.08 & 0.11625 & 0.30 & 1944 & \pm 18 & 1889 & \pm 5 & -3 \\
\hline 1.2 & 439 & 46 & 0.10 & 0.08 & 2.942 & 1.22 & 0.11654 & 0.33 & 1886 & \pm 20 & 1904 & \pm 6 & +1 \\
\hline 2.1 & 207 & 107 & 0.52 & 0.02 & 2.887 & 1.09 & 0.11603 & 0.45 & 1917 & \pm 18 & 1896 & \pm 8 & -1 \\
\hline 3.1 & 215 & 101 & 0.47 & 0.02 & 2.984 & 0.70 & 0.11757 & 0.46 & 1863 & \pm 11 & 1920 & \pm 8 & +3 \\
\hline 4.1 & 494 & 86 & 0.17 & 0.05 & 2.861 & 0.61 & 0.11651 & 0.29 & 1932 & \pm 10 & 1903 & \pm 5 & -2 \\
\hline 5.1 & 211 & 93 & 0.44 & 0.06 & 2.224 & 1.21 & 0.17513 & 0.35 & 2393 & \pm 24 & 2607 & \pm 6 & +10 \\
\hline 6.1 & 142 & 42 & 0.30 & 0.06 & 2.892 & 0.76 & 0.11494 & 0.56 & 1914 & \pm 13 & 1879 & \pm 10 & -2 \\
\hline 7.1 & 295 & 193 & 0.65 & -- & 2.871 & 0.99 & 0.11593 & 0.38 & 1927 & \pm 16 & 1894 & \pm 7 & -2 \\
\hline 7.2 & 179 & 98 & 0.55 & -- & 2.936 & 1.00 & 0.11691 & 0.81 & 1889 & \pm 16 & 1909 & \pm 15 & +1 \\
\hline 8.1 & 765 & 19 & 0.02 & 0.20 & 3.825 & 1.51 & 0.10603 & 0.33 & 1497 & \pm 20 & 1732 & \pm 6 & +15 \\
\hline 9.1 & 971 & 410 & 0.42 & 0.19 & 2.945 & 1.07 & 0.11548 & 0.38 & 1884 & \pm 18 & 1887 & \pm 7 & +0 \\
\hline 10.1 & 771 & 188 & 0.24 & 0.02 & 2.947 & 8.05 & 0.11551 & 4.62 & 1883 & \pm 131 & 1888 & \pm 83 & +0 \\
\hline 11.1 & 253 & 148 & 0.58 & 0.53 & 3.021 & 0.68 & 0.11781 & 0.63 & 1843 & \pm 11 & 1923 & \pm 11 & +5 \\
\hline 11.2 & 89 & 37 & 0.41 & 0.49 & 3.089 & 2.10 & 0.11720 & 2.13 & 1808 & \pm 33 & 1914 & \pm 38 & +6 \\
\hline 12.1 & 600 & 58 & 0.10 & 0.03 & 2.963 & 0.60 & 0.11703 & 0.28 & 1875 & \pm 10 & 1911 & \pm 5 & +2 \\
\hline 13.1 & 208 & 99 & 0.48 & 0.04 & 2.948 & 1.11 & 0.11734 & 0.47 & 1883 & \pm 18 & 1916 & \pm 9 & +2 \\
\hline 14.1 & 598 & 352 & 0.59 & 0.02 & 2.994 & 0.97 & 0.11626 & 0.29 & 1858 & \pm 16 & 1899 & \pm 5 & +3 \\
\hline 14.2 & 176 & 46 & 0.26 & 0.34 & 2.87 & 0.87 & 0.1167 & 0.75 & 1927 & \pm 14 & 1905 & \pm 13 & -1 \\
\hline 15.1 & 499 & 314 & 0.63 & 0.03 & 2.939 & 0.86 & 0.11543 & 0.30 & 1888 & \pm 14 & 1887 & \pm 5 & -0 \\
\hline 16.1 & 141 & 57 & 0.40 & 0.06 & 3.030 & 1.38 & 0.11545 & 0.62 & 1839 & \pm 22 & 1887 & \pm 11 & +3 \\
\hline 16.2 & 663 & 17 & 0.02 & 0.21 & 3.13 & 1.05 & 0.1110 & 0.40 & 1788 & \pm 16 & 1814 & \pm 7 & +2 \\
\hline 17.1 & 239 & 113 & 0.48 & 0.04 & 2.952 & 0.68 & 0.11636 & 0.44 & 1881 & \pm 11 & 1901 & \pm 8 & +1 \\
\hline 17.2 & 151 & 49 & 0.32 & 0.01 & 2.89 & 0.89 & 0.1161 & 0.59 & 1918 & \pm 15 & 1896 & \pm 11 & -1 \\
\hline 18.1 & 290 & 151 & 0.52 & 0.03 & 2.872 & 0.94 & 0.11651 & 0.41 & 1926 & \pm 16 & 1903 & \pm 7 & -1 \\
\hline 19.1 & 319 & 116 & 0.36 & 0.02 & 2.910 & 0.66 & 0.11629 & 0.38 & 1904 & \pm 11 & 1900 & \pm 7 & -0 \\
\hline
\end{tabular}




\section{Bk1336+1337}
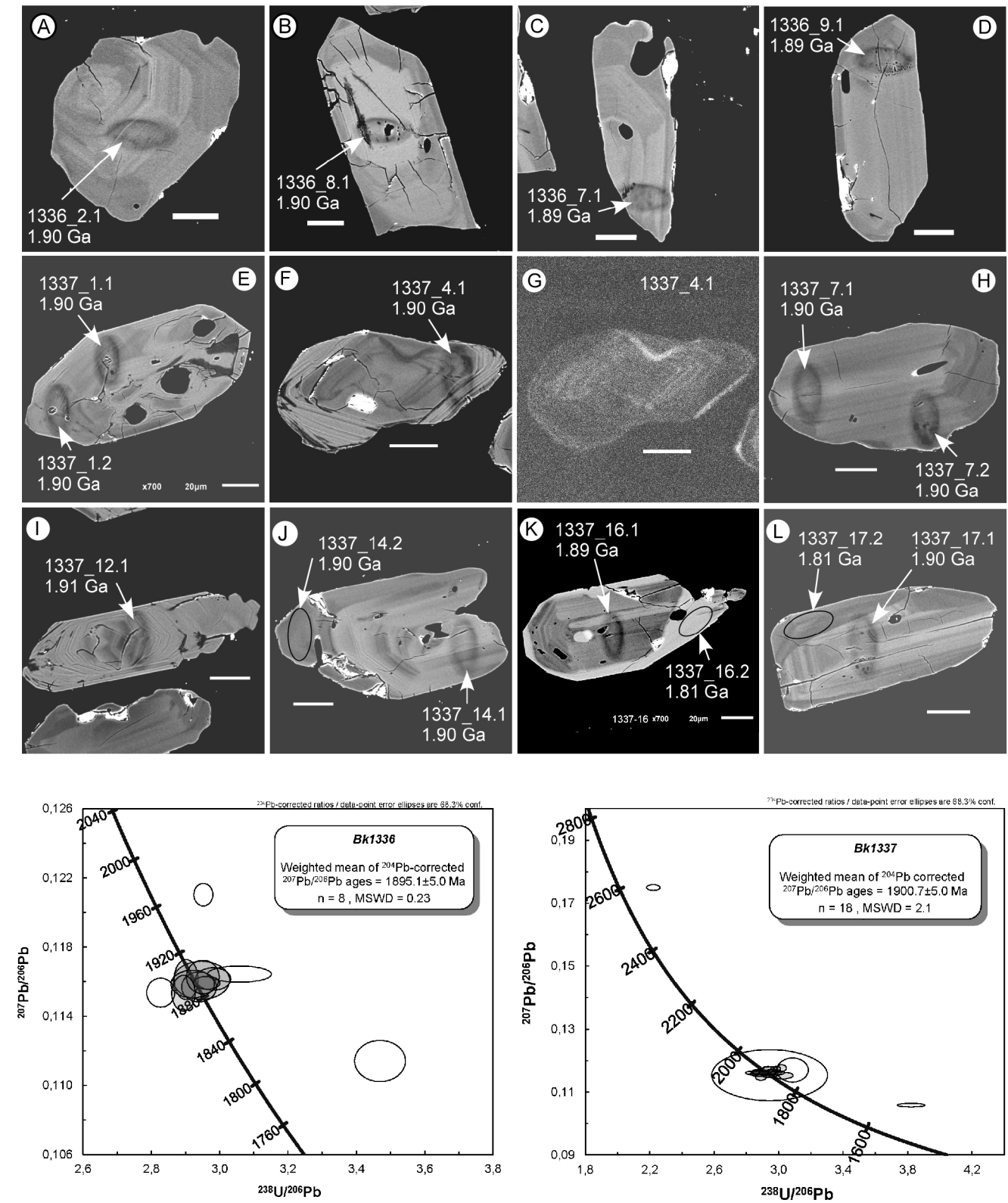

Figure 6. Above: Electron backscatter (and CL - Fig. G) images of zircons from samples Bk1336 and Bk1337, with analysed spots. Scale bar 20 mm. Below: Tera-Wasserburg concordia diagrams for zircons of the samples, with 1-sigma error ellipses for the analysed spots. Unfilled symbols have not been used for the age calculation.

Bk1336

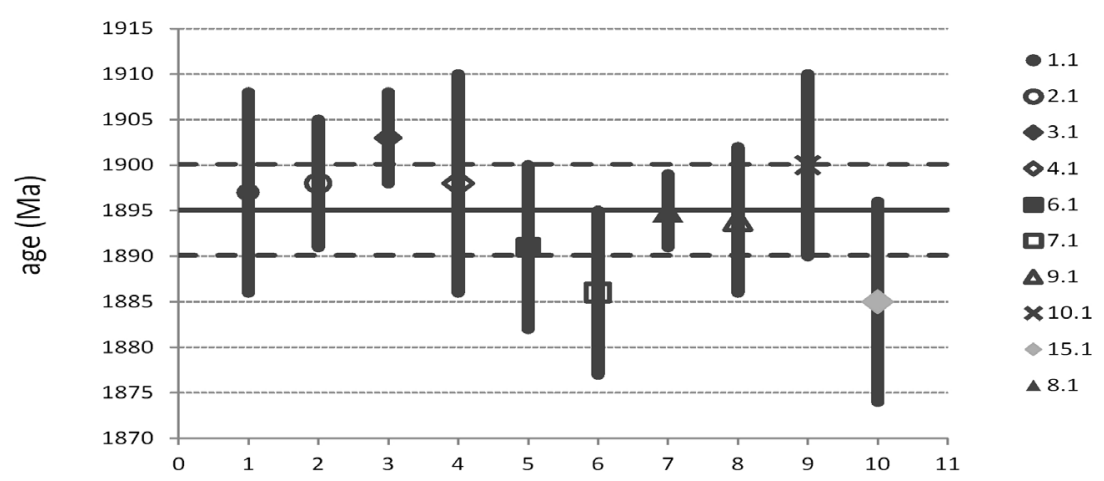

Figure 7. Bar diagram for 10 near-concordant ${ }^{207} \mathrm{~Pb} / 206 \mathrm{~Pb}$ individual spot dates from sample Bk1336. Bar length is 1 -sigma uncertainty for the individual spots. The solid horizontal line plots the aggregate $1895 \mathrm{Ma}$ age (Fig. 6), with 2-sigma uncertainty given by the dashed lines. 


\section{Methods}

Zircons were concentrated at VU University, Amsterdam, by magnetic and centrifugal heavy-liquid separations, followed by hand picking. Both samples delivered euhedral, bipyramidal, colourless, transparent and crystal-clear, 60-90 micrometre, zircon grain-size fractions; some grains had a pinkish hue, a few were somewhat rounded. They were embedded in resin, polished and imaged by backscattered electron and cathode luminescence microscopy, using a JEOL JSM-6610LV scanning electron microscope at the Korean Basic Science Institute (KBSI) in Seoul (Fig. 6, for examples). Most zircons display oscillatory zoning typical for magmatic zircon, further supported by their Th/U ratios $>0.1$ (Table 1; Yakymchuk et al., 2018). Selected spots were U-Th-Pb isotopically analysed by Secondary lon Mass Spectrometry, using the SHRIMP-Ile instrument housed at KBSI, and the 1099 Ma old FC1 zircon standard (Paces \& Miller, 1993). Analytical procedures followed the routine procedures described in Cho et al. (2013). Data reduction and plotting follow Ludwig $(2008,2009)$.

\section{Results}

The ${ }^{207} \mathrm{~Pb} /{ }^{206} \mathrm{~Pb}$ ages in sample Bk1336 cluster mostly between 1.88 and $1.91 \mathrm{Ga}$, which conforms to the known age range of the BG (Stephens et al., 2009). The Tera-Wasserburg diagrams of the data are given in Fig. 7. Eight concordant spots define a weighted mean, ${ }^{204} \mathrm{~Pb}$-corrected, ${ }^{207} \mathrm{~Pb} /{ }^{206} \mathrm{~Pb}$ age of 1895.1 \pm 5.0 Ma with a low MSWD of 0.23 (Figs. 6 \& 7). Results from Bk1337 also peak in the 1.89-1.91 Ga range, but show a pronounced tail to slightly higher ages; 18 near-concordant dates from this sample produce a pooled, ${ }^{204} \mathrm{~Pb}$-corrected, ${ }^{207} \mathrm{~Pb} /{ }^{206} \mathrm{~Pb}$ age of $1900.7 \pm 5.0 \mathrm{Ma}$ (Fig. 6), but its relatively high MSWD value (2.1) as well as the age histogram (not shown) suggest that this population is heterogeneous and could be further unmixed. Both samples also contain some near concordant older, inherited grains, some slightly older than the dominant range, c. $1.92 \mathrm{Ga}$, up to 1.97 and $2.35 \mathrm{Ga}$ (Table 1). One grain in Bk1337 has an isotopically near-concordant, high-U and low Th/U (0.02) overgrowth, discordant to magmatic zoning, with a ${ }^{207} \mathrm{~Pb} /{ }^{206} \mathrm{~Pb}$ age of $1814 \mathrm{Ma}$ (Table 1 \#16.1, Fig. 6K); it may record the age of the amphibolite-facies metamorphism in the area.

\section{Discussion}

Ever since Sundius (1923) described the GF in the nineteen-twenties, no satisfactory explanation for the occurrence of the isolated dolomite megaclast in slates bordering Lake Brunnsjön to the east (Fig. 3) has been offered either by the first author in the nineteen-eighties or by subsequent fieldwork conducted by the SGU (Lundström, 1991). Analysis of aerial photographs resulted in the identification of a smaller extension of the dolomite megaclast to the north. Its falsely west-younging upside-down position in the east-younging sequence is identified here for the first time. Likewise, internal bedding in the isolated megaclast of bedded magnesium-rich leptites farther north is $30^{\circ}$ discordant to the N-S strike of the pebbly slate formation, the Saxhyttan Member of the Grythyttan Slate Formation (Kuipers et al., 2018), in which both megaclasts are embedded. We interpret the two, kilometre-sized megaclasts in the Saxhyttan member as olistoliths. Note that the terms olistostrome and olistolith are derived from subduction- and rifting-related sedimentary facies (Abbate et al., 1970). Large subduction-related sedimentary units (mélanges) are not found in Bergslagen, but in theory an olistostrome with olistoliths could occur along a large crater rim. The latter possibility would turn the whole complex into a volcanogenic sedimentary facies which contradicts the alluvial nature of the local sediments, e.g., slates and turbidites. Large volcanoes with rifting-induced mass gravitational sedimentation therefore 
also seem unlikely. Nevertheless, the layered dolomite megaclast at Lake Brunnsjön must have been derived from a massive carbonate horizon in the underlying metavolcanic sequences and fully overturned during its down-slope sliding. The matrix of the clasts is fine grained and relatively soft in the basal part of the Saxhyttan Formstion. It contains heterolithic conglomerates with, e.g., jaspilite fragments, leptites, dolostones and milky quartz pebbles (from older granites?) from the underlying Sångshyttan Formation. It is difficult to interpret these rocks without the help of a glacial context, supported by its sedimentary facies relationships. Transportation of the megaclasts together with gravel and mud requires a conveyor belt type of transport, which can only be provided by a glacier (Le Heron et al., 2014). We therefore suggest an alluvial glacial facies association for the megaclastic diamict rock type occurring around the olistoliths in the Saxhyttan Member of the Grythyttan Slate Formation. The overlying Torrvarpen conglomerates follow discordantly to the east as a submember of the Saxhyttan member. The lens-shaped conglomerate units were previously interpreted as part of an alluvial-fan type sedimentary facies by Kuipers \& Beunk (2014). The conglomerate lenses represent transverse crosssections through debris flows set in a poorly exposed sandy, pebbly and silty matrix. They have mainly leptitic, quartzitic and slate clasts, but rarely gneissic pebbles (e.g., Fig. $4 \mathrm{~m}$ in Kuipers et al., 2018). The leptitic conglomerate clasts of the Torrvarpen submember show a pronounced orientation (Kuipers et al., 2018), are very well rounded and commonly have an oblong shape as if directed, polished and shaped by ice. The rounding of the clasts, their facetting and sporadic striations, as seen in 2D sections on the flat outcrop surfaces, polished by Pleistocene glaciers, reflect sedimentary abrasion, not tectonic deformation (Kuipers et al., 2018). We now suggest that Palaeoproterozoic glacial processes were the cause of the shapes and rounding. The occurrence of occasional angular leptite clasts in the megaclast diamictite (Fig. 5E) suggests an origin by frost shattering. The abundant angular and subrounded slate pebbles and angular quartz grains in the discordantly overlying conglomerates are derived from the underlying diamictite matrix by glacial abrasion, explaining the angularity of the matrix content. Unfortunately, the consolidated nature of the well exposed Torrvarpen conglomerates, and the Pleistocene glacial polishing of their outcrops seem to minimise any chance of inspection of the pebble surfaces for Palaeoproterozoic glacial striations, this being the strongest possible argument for glacial transportation. Mass transport complexes such as olistostromes (Abbate et al., 1970) or diamictites and debris flows generally result from tectonic disturbance of basin sediments. Here, they are contemporary with early extension of the volcanic back-arc or intra-arc basin $\left(D_{1}\right)$, and the formation of large calderas (Allen et al., 1996; Kuipers et al., 2018). However, a direct causal relationship between deposition by an olistostrome and extensional basin faulting cannot easily be verified in this low-relief terrain with sub-vertically dipping sedimentary bedding, since any $\mathrm{N}$-S-striking $\mathrm{D}_{1}$ normal faults have been rotated into the horizontal by the subsequent $\left(D_{2}\right)$ upright folding of the rocks in the Grythyttan Field (Fig. 2) - they are now either underground or have been eroded away. Yet, an extensional $D_{1}$ fault (caldera rim?), reactivated by $D_{2}$ thrusting, has been interpreted along the eastern margin of the GSB (Kuipers et al., 2018). Alternatively, and/or simultaneously, ice-marginal (glacio)lacustrine or marine environments favour the development of olistrome/diamictite/megaclast suites and could explain the observations presented here (Martini et al., 2011). We suggest that the entire Grythyttan Slate Formation can be interpreted as a progressive sequence of facies from ice-proximal (diamictite) to ice-distal (grey and black slates), bearing a close similarity to the Neoproterozoic glacigenic olistostrome complexes reported from Death Valley, California, where debris flows, underlying diamictite and overlying sandstone channels, form an ice-contact depositional system or fan (Le Heron et al., 2014, 2017). 


\section{Carbonate rocks and banded iron formations of the Sångshyttan Formation}

The metavolcaniclastic Sångshyttan Fm underlying the GSB (Fig. 3) contains significant volumes of carbonate rocks (e.g., Fig. 2) and banded ironstones. Microbial mats have been recognised by Oen et al. (1986) and Boekschoten et al. (1988) in the Grythyttan slates $1 \mathrm{~km}$ south of Grythyttan. Among others, Wharton (1994) and Andersen et al. (2011) studied the modern stromatolitic microbial mats in perennially ice-covered lakes of Antarctica, providing a better understanding of stromatolite-bearing limestone formations in general and their relation to Precambrian glaciations. They contradict the common misconception that stromatolites, or carbonate rocks in general, were formed exclusively in warm climates (Walter \& Bauld, 1983; see also e.g., Prasada Rao, 1981; Shields, 2005; Cooper et al., 2013). Stromatolites in the Proterozoic Bergslagen Group suggest microbial fixation of carbonate on a grand scale, and do not exclude a cold-water environment. At the same time, iron formations were formed, possibly due to cyanobacteria (algae) producing ferric oxide, resulting in dolomites and BIF layers in the Sångshyttan Formation. Primary microbially mediated carbonates are apparently reworked and redeposited, as witnessed by the channel structure in the Brunnsjön olistolith (Fig. $5 \mathrm{H}$ ). We note that the data available so far (Allen et al., 2008; Beunk, unpublished data) failed to reveal pronounced negative $\delta^{13} \mathrm{C}$ values similar to those characterising Neoproterozoic carbonates coincident with glaciations (G. M. Young, pers. comm. 2018). The glacial sediments of the GSB and the ice-wedge cast near Ställdalen are evidence for an arctic climate at low latitudes at around $1.9 \mathrm{Ga}$. After $1 \mathrm{Ga}$, the same conditions prevailed again in the Cryogenian, also marked by (cap)carbonates and BIFs during a long cold interval (the so-called 'Snowball Earth' period, Fig. 1). From then on, no BIFs have been formed on a substantial scale, most likely because oxygenation of the oceanic water column prohibited dispersal of soluble hydrothermal $\mathrm{Fe}^{2+}$.

\section{Conclusions}

We offer a glacigenic interpretation for the megaclastic sedimentary-facies association in the Palaeoproterozoic Bergslagen Group of the Grythyttan Field. The deposits formed at $1894.5 \pm 2.8 \mathrm{Ma}$, within the 1.5 Gy-long 'Proterozoic glacial gap' (Eyles, 2008). They are broadly coeval with a peak in the worldwide abundance of Banded Iron Formations (Fig.1). The angular nature of the dolomitic olistoliths in the Brunnsjön diamictite, composed of preglacial calcareous sedimentary material, suggests a local source and minimal transport. This interpretation is corroborated by the occurrence of heterolithic conglomerates in the diamictite, with jaspilite fragments of the preglacial BIFs, and suggests both glacial and slope processesses reworking the BIFs, leptites and dolostones, and quartz vein remnants, possibly from older granites or gneisses. Synsedimentary periglacial macrostructures developed in coeval thin-bedded metadacitic volcanic deposits of the Bergslagen Group. These structures survived polyphase deformation and amphibolite-facies metamorphism thanks to the absence of localised penetrative shearing. Deposition of the host dacites was dated by SIMS U-Th-Pb geochronology of zircons at $1895 \pm 5 \mathrm{Ma}$. While the Bergslagen Group sediments are dominantly of shallow water type, the periglacial structures and previously documented evidence for local subaerial deposition are indicative of a lowland depositional environment punctuated by large volcanic complexes (cf., Taupo volcanic zone, N. New Zealand). The volcaniclastic facies are in two places interrupted by glacial and periglacial deposits, the latter described by Kuipers et al. (2013) and Vandenberghe et al. (2020). The previously described alluvial fan south of Grythyttan (Kuipers \& Beunk, 2014) is now recognised as part of a glacial sedimentary-facies assemblage. The evidence consists of the occurrence of (1) megaclasts and sporadic dropstones in a heterolithic diamictite, (2) flatiron-type clasts in the overlying debris-flow conglomerate, (3) mainly rounded clasts in an angular matrix and (4) 
occasional striatons on cobble surfaces in this Torrvarpen conglomerate. Until now, the only direct evidence of Orosirian continental glaciation at low latitude is known from N. Australia, at around $1.8 \mathrm{Ga}$ (Williams, 2005), but recently Rodriguez-Lopez et al. (2021) reveal that the Palaeoproterozoic (2.1-1.86 Ga) Chaibasa Formation in the Dhalbhumgarh area, eastern India, represents sedimentation in an ice-contact proglacial lagoon affected by iceberg calving and lake-ice rafting.

Between 2.1 and $1.8 \mathrm{Ga}$, Earth experienced possibly intermittent (sub)polar climates at low latitudes. Extensive explosive volcanism along the active margin of Columbia and the $15 \%$ lower-thanpresent solar luminosity of the time (Sagan \& Mullen, 1972; Feulner, 2012) may have contributed to the climatic minimum. Eyles (2008), Nance \& Murphy (2013) and Young (2018) have related the episodic nature of the glaciations (Fig. 1) to the supercontinent cycle, more specifically to enhanced weathering and drawdown of atmospheric $\mathrm{CO}_{2}$ at times of supercontinent amalgamation or break-up. It is beyond the scope of this report to decide whether the evidence of Proterozoic glaciations at low latitude, in contrast to their Phanerozoic equivalents, supports a Snowball Earth scenario, spreading from high to low latitude, or if the hypothesis of Williams (1975, 2008; also Williams et al., 2016) of a high obliquity of Earth's spin axis during the Proterozoic Eon and initiation of glaciation at low latitude (Young, 2018) is more relevant. The $1.9 \mathrm{Ga}$ glacial period seems to be the first in Earth's history linked to the stage of assembly of a supercontinent (Fig. 1; the 'A-type glaciation' of Young, 2018).

Acknowledgements. The authors acknowledge funding for field and analytical work from the Dutch Dr. Schürmann Foundation for Precambrian research (www.dr-schurmannfonds.nl, grants 71/2010,75/2011, 97/2014). We are indebted to Dr. P.F. Hoffman for critical remarks on a previous version of the manuscript but we are solely responsible for our interpretations. The final version was improved following constructive reviews by Drs D. Le Heron and M. Busfield.

\section{References}

Abbate, E., Bortolotti, V. \& Passerini, P. 1970: Olistostromes and olistoliths. In Sestini, G. (ed.): Development of the Northern Apennines geosyncline, Sedimentary Geology 4, pp. 521-557. https://doi.org/10.1016/0037-0738(70)90022-9.

Allen, R.L., Lundström, I., Ripa, M., Simeonov, A. \& Christofferson, H. 1996: Facies analysis of a 1.9 $\mathrm{Ga}$, continental margin, back-arc, felsic caldera province with diverse $\mathrm{Zn}-\mathrm{Pb}-\mathrm{Ag}-(\mathrm{Cu}-\mathrm{Au})$ sulfide and Fe oxide deposits, Bergslagen Region, Sweden. Economic Geology 91, 979-1008. https://doi.org/10.2113/gsecongeo.91.6.979.

Allen, R., Ripa, M. \& Jansson, N. 2008: Palaeoproterozoic volcanic and limestone hosted $\mathrm{Zn}-\mathrm{Pb}-\mathrm{Ag}$ $(\mathrm{Cu}-\mathrm{Au})$ massive sulphide deposits and Fe oxide deposits in Bergslagen, Sweden. 33 IGC excursion No.12, 14-20 August.

Andersen, D.T., Sumner, D.Y., Hawes, I., Webster-Brown, J. \& McKay, C.-P. 2011: Discovery of large conical stromatolites in Lake Untersee, Antarctica. Geobiology 9, 280-293.

https://doi.org/10.1111/j.1472-4669.2011.00279.x.

Beunk, F.F. \& Kuipers, G. 2012: The Bergslagen ore province, Sweden: Review and update of an accreted orocline, 1.9-1.8 Ga BP. Precambrian Research 216-219, 95-119.

https://doi.org/10.1016/j.precamres.2012.05.007. 
Beunk, F.F. \& Valbracht, P.J. 1991: Early Proterozoic continental tholeiites from western Bergslagen, Central Sweden: III. Geodynamic inferences. Precambrian Research 52, 231-234. https://doi.org/10.1016/0301-9268(91)90082-L.

Boekschoten, G.J., Van der Raad, A.C., Kenter, J.A.M. \& Reijmer, J.J.G. 1988: Note on a mid-Proterozoic stromatolite limestone, South of Grythyttan, Bergslagen, Sweden. Geologie en Mijnbouw (Netherlands Journal of Geosciences) 67, 467-470.

Cho, M., Cheong, W., Ernst, W.G., Yi, K. \& Kim, J. 2013. SHRIMP U-Pb ages of detrital zircons in metasedimentary rocks of the central Ogcheon fold-thrust belt, Korea: evidence for tectonic assembly of Palaeozoic sedimentary protoliths. J. Asian Earth Sci. 63, 234-249.

https://doi.org/10.1016/j.jseaes.2012.08.020.

Cooper, J.A.G., Smith, A.M. \& Arnscheidt, J. 2013: Contemporary stromatolite formation in high intertidal rock pools, Giant's Causeway, Northern Ireland: preliminary observations. In Conley, D.C., Masselink, G., Russell, P.E. \& O'Hare, T.J. (eds.): Proceedings 12th International Coastal Symposium (Plymouth, England), Journal of Coastal Research, Special 407 Issue 65, pp. 1675-1680. https://doi.org/10.2112/SI65-283.1.

Eyles, N. 2008: Glacio-epochs and the supercontinent cycle after 3.0 Ga: Tectonic boundary conditions for glaciation. Palaeogeography, Palaeoclimatology, Palaeoecology, 89-129.

https://doi.org/10.1016/j.palaeo.2007.09.021.

Feulner, G. 2012: The faint young sun problem. Reviews of Geophysics 50, RG2006, 29 pp. https://doi.org/10.1029/2011RG000375.

Hoffman, P.F. \& Schrag, D.P. 2002: The snowball Earth hypothesis: testing the limits of global change. Terra Nova 14, 129-155. https://doi.org/10.1046/j.1365-3121.2002.00408.x.

Kuipers, G. 1987: Volcaniclastic facies associations in the Mid-Proterozoic Grythyttan rift-basin and their lithostratigraphic relationship, West-Bergslagen, Central Sweden. Geologische Uitgaven Amsterdam Papers of Geology 1, 162 pp.

Kuipers, G. \& Beunk, F.F. 2014: The Proterozoic (1.85 Ga) Älvestorp Conglomerate, Bergslagen, Central Sweden. Geology Today 30, 222-226. https://doi.org/10.1111/gto.12077.

Kuipers, G., Beunk, F.F. \& Van der Wateren, F.M. 2013: Periglacial evidence for a 1.91-1.89 Ga 419 old glacial period at low latitude, Central Sweden. Geology Today 29, 218-221.

https://doi.org/10.1111/gto.12027.

Kuipers, G., Beunk, F.F., Yi, K. \& Van der Wateren, F.M. 2018: The Paleoproterozoic Grythyttan Field in the Svecofennian Orogen, West Bergslagen, Central Sweden: Structure, Stratigraphy and Age. Norwegian Journal of Geology 98, 333-357. https://doi.org/10.17850/njg98-3-05.

Le Heron, D.P., Busfield, M.E. \& Prave, A.R. 2014: Neoproterozoic ice sheets and olistoliths: Multiple glacial cycles in the Kingston Peak Formation, California. Journal of the Geological Society 171, 525-538. https://doi.org/10.1144/jgs2013-130.

Le Heron, D.P., Tofaif, S., Vandyk, T. \& Ali, D.O. 2017: A diamictite dichotomy: Glacial conveyor belts and olistostromes in the Neoproterozoic of Death Valley, California, USA. Geology 45, 31-34. https://doi.org/10.1130/G38460.1. 
Lisle, R., Rondeel, H.E., Doorn, D., Brugge, J. \& van der Gaag, P. 1983. Estimation of viscosity contrast and finite strain from deformed elliptical inclusions. J. Structural Geol. 5 (6), 603-609.

Ludwig, K.R. 2008: User's manual for Isoplot 3.6: a geochronological toolkit for Microsoft Excel. Berkeley Geochronology Center Special Publication 4, 77 pp.

Ludwig, K.R. 2009: SQUID 2: a user's manual. Berkeley Geochronology Center Special publication 2, 100 pp.

Lundström, I. 1991: 11E Filipstad SO, scale 1:50.000, serie Af nr. 177, Sveriges Geologiska Undersökning.

Martini, I.P., French, H.M. \& Perez Alberti, A. 2011: Ice-marginal and periglacial processes and sediments: an introduction. Geological Society, London, Special Publication 354, 1-13. https://doi.org/10.1144/SP354.1.

Meert, J.G. \& Santosh, M. 2017: The Columbia supercontinent revisited. Gondwana Research 50, 67-83. https://doi.org/10.1016/j.gr.2017.04.011.

Mertanen S. \& Pesonen, L.J. 2012: Chapter 2. Paleo-Mesoproterozoic Assemblages of Continents: Paleomagnetic Evidence for Near Equatorial Supercontinents. In Haapala, I. (ed.): From the 446 Earth's Core to Outer Space, Lecture Notes in Earth System Sciences 137, pp. 11-35.

https://doi.org/10.1007/978-3-642-25550-2_2.

Nance, R.D. \& Murphy, J.D. 2013: Origins of the supercontinent cycle. Geoscience Frontiers 4, 439-448. https://doi.org/10.1016/j.gsf.2012.12.007.

Nance, R.D., Murphy, J.D. \& Santosh, M. 2014: The supercontinent cycle: A retrospective essay. Gondwana Research 25, 4-29. https://doi.org/10.1016/j.gr.2012.12.026.

Oen, I.S., De Maesschalk, A.A. \& Lustenhouwer, W.J. 1986: Mid-Proterozoic exhalative 452 sedimentary Mn-skarns containing possible microbial fossils, Grythyttan, Bergslagen, 453 Sweden. Economic Geology 81, 1533-1543. https://doi.org/10.2113/gsecongeo.81.6.1533.

Paces, J.B. \& Miller, J.D. 1993: Precise U-Pb ages of Duluth Complex and related mafic intrusions, northeastern Minnesota: geochronological insights to physical, petrogenetic, paleomagnetic, and tectonomagmatic processes associated with the $1.1 \mathrm{Ga}$ midcontinent rift system. Journal of Geophysical Research 98, 13997-14013. https://doi.org/10.1029/93JB01159.

Pesonen, L.J., Mertanen, S. \& Veikkolainen, T. 2012: Paleo-Meso-Proterozoic Supercontinents A Paleomagnetic View. Geophysica 48, 5-47.

Prasada Rao, C. 1981: Criteria for recognition of cold-water carbonate sedimentation: Berriedale limestone (Lower Permian), Tasmania, Australia. Journal of Sedimentary Petrology 51, 491-506.

https://doi.org/10.1306/212F7CC0-2B24-11D7-8648000102C1865D.

Rodrigues-Lopez, J.P., Van Vliet-Lanoë, B., Lopez-Martinez, J. \& Martin-Garcia., R. 2021: Scouring by rafted ice and cryogenic patterned ground preserved in a Palaeoproterozoic equatorial proglacial lagoon succession, eastern India, Nuna supercontinent. Marine and Petroleum Geology Volume 123, 104766. https://doi.org/10.1016/j.marpetgeo.2020.104766. 
Rogers, J.J.W. \& Santosh, M. 2002: Configuration of Columbia, a Mesoproterozoic Supercontinent. Gondwana Research 5, 5-22. https://doi.org/10.1016/S1342-937X(05)70883-2.

Sagan, C. \& Mullen, G. 1972: Earth and Mars, evolution of atmospheres and surface temperatures. Science 177, 52-56. https://doi.org/10.1126/science.177.4043.52.

Shields, G.A. 2005: Neoproterozoic cap carbonates: a critical appraisal of existing models and the plumeworld hypothesis. Terra Nova 17, 299-310. https://doi.org/10.1111/j.1365-3121.2005.00638.x.

Stephens, M.B., Ripa, M., Lundström, I., Persson, L., Bergman, T., Ahl, M., Wahlgren, C.-H., Persson, P.-O. \& Wikström, L. 2009: Synthesis of the bedrock geology in the Bergslagen region, Fennoscandian Shield, south-central Sweden. Sveriges Geologiska Undersökning, Ba58, 259 pp.

Sundius, N. 1923. Grythyttefältets geologi. Sveriges Geologiska Undersökning, Ser. C 312, 353 pp.

Terry J.P. \& Goff, J. 2014: Megaclasts: Proposed Revised Nomenclature At the Coarse End of the Udden-Wentworth Grain-Size Scale for Sedimentary Particles. Journal of Sedimentary Research 84, 192-197. https://doi.org/10.2110/jsr.2014.19.

Tucker, M.E. 2003: Sedimentary Rocks in the Field. John Wiley \& Sons, New York, 244 pp.

Vandenberghe, J., Kuipers, G., Beunk, F.F., Yi, K. \& van der Wateren, F.M. 2020: Evidence of permafrost in the Palaeoproterzoic (c. $1.9 \mathrm{Ga}$ ) of Central Sweden. Permafrost and Periglacial Processes, 1-9. https://doi.org/10.1002/ppp.2094.

Walter, M.R. \& Bauld, J. 1983: The association of sulphate evaporites, stromatolitic carbonates and glacial sediments: examples from the Proterozoic of Australia and the Cainozoic of Antarctica. Precambrian Research 21, 129-148. https://doi.org/10.1016/0301-9268(83)90008-6.

Wharton Jr., R.A. 1994: Stromatolitic mats in Antarctic lakes. In Bertrand-Sarfati, J. \& Monty, C. (eds.): Phanerozoic stromatolites II. Kluwer Academic Publishers, pp. 53-70.

https://doi.org/10.1007/978-94-011-1124-9_3.

Williams, G.E. 1975: Late Precambrian glacial climate and the Earth's obliquity. Geological Magazine 112, 441-465. https://doi.org/10.1017/S0016756800046185.

Williams, G.E. 2005: Subglacial meltwater channels and glaciofluvial deposits in the Kimberley Basin, Western Australia: $1.8 \mathrm{Ga}$ low-latitude glaciation coeval with continental assembly. Journal geological Society of London 162, 111-124. https://doi.org/10.1144/0016-764903-157.

Williams, G.E. 2008: Proterozoic (pre-Ediacaran) glaciation and the high-obliquity, low-latitude ice, strong seasonality (HOLIST) hypothesis: principles and tests. Earth-Science Reviews 87, 61-93. https://doi.org/10.1016/j.earscirev.2007.11.002.

Williams, G.E., Schmidt, P.W. \& Young, G.M. 2016: Strongly seasonal Proterozoic glacial climate in low palaeolatitudes: Radically different climate system on the pre-Ediacaran Earth. Geoscience Frontiers 7, 555-571. https://doi.org/10.1016/j.gsf.2016.01.005.

Yakymchuk, C., Kirkland, C.L. \& Clark, C. 2018: Th/U ratios in metamorphic zircon. Journal of metamorphic Geology 36, 715-737. https://doi.org/10.1111/jmg.12307. 
Young, G.M. 2018: Chapter 2 - Precambrian glacial deposits: their origin, tectonic setting, and key role in Earth evolution. In Menzies, J. \& Van der Meer, J.J.M. (eds.): Past Glacial Environments, $2^{\text {nd }}$ Ed., Elsevier, pp. 17-45. https://doi.org/10.1016/B978-0-08-100524-8.00001-4.

Zhao, G., Sun, M., Wilde, S.A. \& Li, S. 2004: A Paleo-Mesoproterozoic supercontinent: assembly, growth and breakup. Earth-Science Reviews 67, 91-123. https://doi.org/10.1016/j.earscirev.2004.02.003. 